短 報 Japanese Journal of Health Promotion and Physical Therapy Vol. 4, No. 2： 83-86, 2014

高齢者のための新たな歩行能力評価法の開発

$-50 \mathrm{~m}$ 歩行テストの妥当性

\title{
Development of a New Gait Assessment Scale for the Elderly -Examining the Validity of a $50 \mathrm{~m}$ Walk Test
}

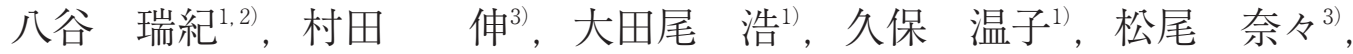 \\ 甲斐 義浩 ${ }^{3)}$, 政所 和也 ${ }^{4)}$, 溝田 勝彦 ${ }^{1)}$, 山元 章生 ${ }^{5)}$, 浅見 豊子 ${ }^{2)}$
}

Mizuki Hachiy ${ }^{1,2)}$ ， Shin Murata ${ }^{3)}$ ， Hiroshi OtaO1)， Atsuko Kubo1)， Nana Matsuo3),

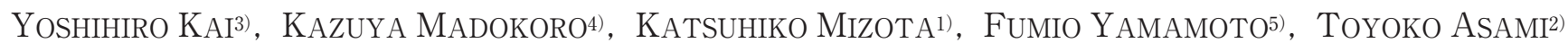

\begin{abstract}
要旨：本研究の目的は, 高齢者の歩行能力の評価指標として開発した $50 \mathrm{~m}$ 歩行テストの妥 当性を検討することである。健常な地域在住高齢者男性13名（平均71.0歳）を対象に, 50 $\mathrm{m}$ の所要時間および $10 \mathrm{~m}$ 毎の所要時間（ラップ 1〜 5 ), $5 \mathrm{~m}$ 歩行時間, 大腿四頭筋筋力, 30秒椅子立ち上がりテスト (CS-30), 開眼片足立ちテスト, Timed Up \& Go Test (TUG) を測定した。ラップ 1 とラップ 5 を除いたラップ 2 た 4 までの $10 \mathrm{~m}$ 毎の所要時間を比較し た結果，すべてのラップ間に有意な差は認められず歩行時間は安定していた。また，歩行 能力と身体機能との関連を分析したところ，50m歩行テストは大腿四頭筋筋力， CS-30, 開眼片足立ちテスト，TUG と有意な相関が認められた。一方， $5 \mathrm{~m}$ 歩行時間では，CS30と開眼片足立ちテストとの間には有意な相関は認められなかった。従来から歩行能力の 指標として用いられている $5 \mathrm{~m}$ 歩行時間よりも，50m歩行テストの方が高齢者の身体機能 をより反映することが確認され，歩行能力の評価法として有用であることが示唆された。

キーワード： $50 \mathrm{~m}$ 歩行テスト, 歩行能力, 高齢者

Abstract: This study examined the validity of a $50 \mathrm{~m}$ walk test to assess the elderly's gait ability. The following items were measured, involving 13 elderly (mean age: 71.0 ) males living in the community: the times needed to walk $50 \mathrm{~m}, 10 \mathrm{~m}$ between laps (1 to 5), and $5 \mathrm{~m}$; quadriceps muscle strength; and 30-Second Chair Stand (CS-30), Standing on one leg with eyes open, and Timed Up \& Go (TUG) test scores. On comparison of the times needed to walk $10 \mathrm{~m}$ between laps, no significant differences were observed, indicating that the participants walked at a stable pace. Regarding the association between the gait ability and physical function, the results of the $50 \mathrm{~m}$ walk test were significantly correlated with the quadriceps muscle strength, as well as CS-30, Standing on one leg with eyes open, and TUG test scores. On the other hand, the time needed to walk $5 \mathrm{~m}$ showed a significant correlation only with the quadriceps muscle strength and TUG test scores. These results confirmed that the $50 \mathrm{~m}$ walk test reflects healthy elderly males' physical function more accurately than the time needed to walk $5 \mathrm{~m}$ as a conventional index for gait assessment.
\end{abstract}

Key words: $50 \mathrm{~m}$ walk test, gait ability, elderly

\footnotetext{
受付日：2014年 4 月 4 日, 採択日：2014年 5 月14日

1) 西九州大学 リハビリテーション学部

佐賀県神埼市神埼町尾崎4490- 9 （下842-8585）

TEL : 0952-52-4191 e-mail : hachiyami@nisikyu-u.ac.jp

Faculty of Rehabilitation Science, Nishikyushu University 4490-9 Ozaki, Kanzaki, Saga 842-8585, JAPAN.

TEL+81-952-52-4191 e-mail: hachiyami@nisikyu-u.ac.jp

2) 佐賀大学大学院 医学系研究科

Graduate School of Medicine, Saga University

3) 京都橘大学 健康科学部

Faculty of Health Science, Kyoto Tachibana University

4) 医療福祉専門学校緑生館 理学療法学科

Technical School of Medical and Welfare Ryokuseikan

5) 山元記念病院

Yamamoto Memorial Hospital
} 


\section{I はじめに}

高齢者における移動能力の確保は，自立生活を行う ために重要である。移動におけるもっとも基本的な動 作は歩行であることから，これまで歩行に関する報告 が数多くなされてきた ${ }^{1-3)}$ 。歩行能力の評価には $5 \mathrm{~m}$ $10 \mathrm{~m}$ 歩行テスト ${ }^{1-6}$ が, 応用歩行能力の評価に $10 \mathrm{~m}$ 障害 物歩行 ${ }^{7.8)}$ などがある。その他に，歩行を用いた全身持 久力の指標には 6 分間歩行試験 ${ }^{9}$ がある。歩行速度は 機能障害や生存率などとの関連を認めることから，身 体機能を反映する有用な評価法である。また, 年代別 参考值が示されていること的や，簡便な評価法である ことから，歩行速度は汎用性が高い評価法である。

一方, Buchner ら ${ }^{11}$ は歩行速度による下肢機能の評 価には天井効果が認められると報告している。つまり， 被験者の歩行速度を低下させるほど下肢筋力が低下し ている場合は, 歩行速度と下肢筋力との間に相関関係 を認めるが，正常歩行を行える者では，下肢筋力がさ らに改善したとしても歩行速度には反映されないとし ている。これは, $5 \mathrm{~m}$ および $10 \mathrm{~m}$ 歩行テストは, 疾患 を有する者や虚弱高齢者の歩行能力評価として有用で あるが，健常な高齢者では身体機能を的確に把握でき るとは言い切れないことを意味する。American Thoracic Society（アメリカ胸部疾患学会）のガイドライ ン9によよと 6 分間歩行試験の歩行路は $30 \mathrm{~m}$ の長さが 必要とされている。ただし, 歩行路の確保が困難な施 設が多いことから実用的とは言い難い。

そこで著者らは，多くの医療機関や介護施設で確保 されている $10 \mathrm{~m}$ 歩行路を利用し, 歩行路を往復するこ とで歩行能力を評価する「50m歩行テスト」を考案し
た。本研究ではその測定法の紹介とともに, 50m歩行 テストの基準関連妥当性について検討した。

\section{II 方 法 \\ 1. 対 象}

高齢者用フィットネスジムを利用している地域在住 の男性13名を対象とした。対象者の年齢は71. $0 \pm 3.7$ 歳 (平均土標準偏差), 身長は162.9 $06.3 \mathrm{~cm}$, 体重は $62.1 \pm 5.7 \mathrm{~kg}$ であった。除外基準は, 加療を要する神 経疾患, 骨関節系疾患がある者とした。なお，対象者 は自宅生活が自立しており, 自家用車などで自ら調査 に参加できる者であった。

倫理的配慮として, 本研究はヘルシンキ宣言に従っ た。対象者に研究の趣旨と内容を十分に説明し, 同意 を得たうえで測定を開始した。また，研究の参加は自 由意思であること, 参加しない場合や中途で中止をし ても不利益がないことを説明した。個人情報保護の遵 守を伝え, デー夕管理は厳重に行った。本研究は, 事 前に施設の施設長，現場責任者の承認を得て実施した。

\section{2. 方 法}

歩行能力の評価は, $50 \mathrm{~m}$ 歩行テストの他, $5 \mathrm{~m}$ 歩行 時間を実施した。身体機能は, 大腿四頭筋筋力, 30秒 椅子立ち上がりテスト (30-second chair stand test: CS -30), 開眼片足立ちテスト, Timed Up \& Go Test （TUG）を評価した。

$50 \mathrm{~m}$ 歩行テスト（図 1 ）は, $10 \mathrm{~m}$ の歩行路間に配置 したコーンを 2.5 往復折り返して合計 $50 \mathrm{~m}$ 歩いても らう。測定は歩行開始から $50 \mathrm{~m}$ に到達するまでの所要
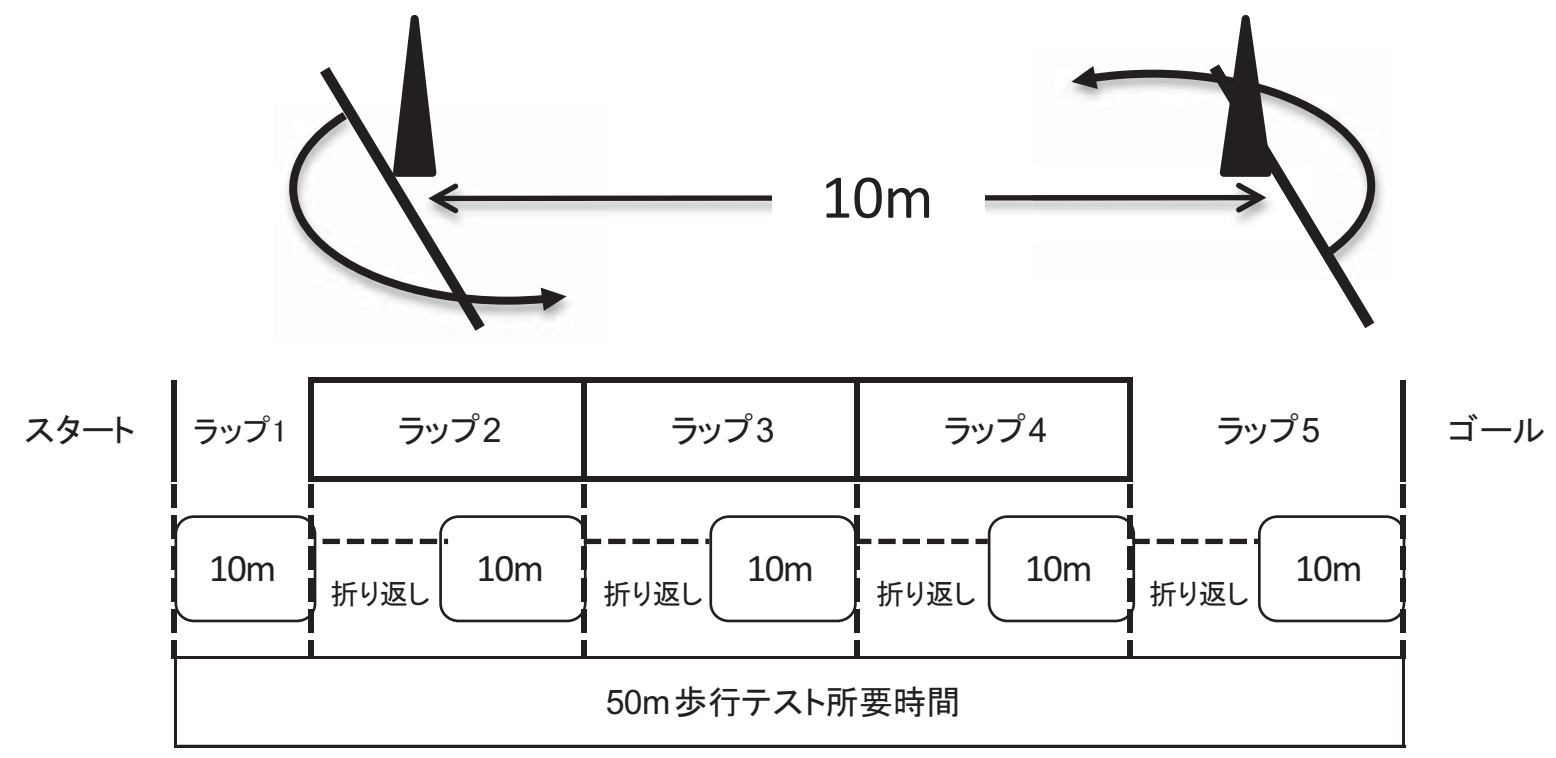

図 1.50m歩行テストの測定モデル図 
時間をストップウォッチで測定した。準備するものは, $10 \mathrm{~m}$ の歩行路, 方向転換時の目印 (コーン), ラップ タイム機能付きのストップウォッチである。測定方法 は, 開始前の姿勢は静止立位とし，コーンの横に立つ。 対象者には, 検査者の合図で歩き出すこと, 目印の外 側を往復することを伝えた。その際の歩行条件は最速 歩行とした。10mの歩行路を 2.5 往復する間は休憩を 入れず連続して歩行させた。ストップウォッチの操作 は, 歩行開始から $40 \mathrm{~m}$ （2 往復目）までは $10 \mathrm{~m}$ 毎に区 間経過時間の計測を行い，50m終了時にストップを押 す。記録する評価項目は, $50 \mathrm{~m}$ 歩行の所要時間（秒), およびラップタイム機能で計測したラップ 1 〜ラップ

5 の $10 \mathrm{~m}$ 毎の所要時間（秒）である。なお，「ラッ プ」とは一方のコーンから $10 \mathrm{~m}$ 先にあるコーンまでの 区間距離と定義した。

$5 \mathrm{~m}$ 歩行時間 ${ }^{13)}$ は, 平地 $5 \mathrm{~m}$ の最速歩行の所要時間 をストップウォッチで測定した。なお，歩行開始と終 了時の加速と減速を考慮し, 測定区間の前後に予備区 間を 3 m確保し計 $11 \mathrm{~m}$ を歩行区間とした。測定は, 2 回行いその最短值（秒）を代表值として採用した。

大腿四頭筋筋力 ${ }^{14)}$ の測定には, ハンドヘルドダイナ モメーター（アニマ社製等尺性筋力測定装置 $\mu$ Tas F ー1）を用いた。対象者をプラットホーム上で端坐位, 膝関節90度屈曲位とさせた。パッドを下腿遠位部に設 置した上で，この測定装置をべルトで固定し，測定時 に殿部が治療台から浮かないように留意した。最大等 尺性収縮筋力を左右ともに 2 回測定し, その最大值を 代表値として採用し体重比百分率（\%）に換算した。

CS-30は，中谷ら ${ }^{15)} の$ 方法に準じて実施した。坐面 の高さが40cmの背もたれのない椅子に坐位姿勢となり， 両上肢を前方で組み開始肢位とした。「はじめ」の合 図により開始肢位から立ち上がりを行い，直立姿勢ま で立った後，すぐに着座するまでの動作を 1 回とし， 30秒間での立ち上がり回数（回）を測定した。ただし， 立ち上がり途中で30秒を経過した場合は回数に含めな かった。

開眼片足立ちテスト ${ }^{14)}$ は，上肢の支持がない状態で 安定した静止立位となったところで, 対象者の任意の タイミングで一側の下肢を挙上させ，片足立ちを保持 できた時間をストップウォッチで測定した。測定の際, $2 \mathrm{~m}$ 前方の視線と同じ高さの目印を注視するように伝 えた。測定を終了とする判断は，支持脚が計測開始時 の位置から移動した場合, 挙上した下肢が床に触れた 場合のいずれかとした。また，120秒を保持時間の上
限值に設定した。測定は左右ともに 2 回ずつ行い, そ の最長值（秒）を代表值として採用した。

$\mathrm{TUG}^{12}$ は，坐面の高さが $40 \mathrm{~cm}$ の时掛けのない椅子に 腰掛けた姿勢から, 開始の合図で歩き出し $3 \mathrm{~m}$ 前方に 配置したポールを回って着座するまでの時間をストッ プウォッチで測定した。歩行の条件は最速歩行で行う ように説明した。測定は 2 回行いその最速值（秒）を 代表値として採用した。

統計学的分析は, $50 \mathrm{~m}$ 歩行テストのラップ 1 とラッ プ 5 を除く, ラップ 2 からラップ 4 までの各区間から 得られた所要時間を一元配置分散分析で比較した。ま た, $50 \mathrm{~m}$ 歩行テストおよび $5 \mathrm{~m}$ 歩行時間の測定值と, 身体機能の測定值との関連をピアソンの相関係数を用 いて検討した。なお，統計解析にはSPSS19. 0 (IBM 社製）を用い有意水準は $5 \%$ 未満とした。

\section{III 結 果}

対象者の各測定值の平均值と標準偏差を表 1 に示し た。 $50 \mathrm{~m}$ 歩行テストのラップ 2 からラップ 4 より得ら れた所要時間を比較した結果，すべての区間に有意な 差は認められなかった（ $\mathrm{F}=0.20, p=0.82 ） 。$

$50 \mathrm{~m}$ 歩行テストおよび $5 \mathrm{~m}$ 歩行時間と各身体機能と の相関分析の結果, $50 \mathrm{~m}$ 歩行テス卜は大腿四頭筋筋力 $(\mathrm{r}=-0.62, \mathrm{p}<0.05), \mathrm{CS}-30(\mathrm{r}=-0.90, \mathrm{p}<0.01)$, 開眼片足立ちテスト $(r=-0.70, \mathrm{p}<0.05), \quad$ TUG $(r$ $=0.89, \mathrm{p}<0.01 ）$ と有意な相関が認められた。一方, $5 \mathrm{~m}$ 歩行時間は, 大腿四頭筋筋力 $(r=-0.57, \mathrm{p}<$ 0.05), TUG $(r=0.62, p<0.05)$ との間に有意な相 関が認められたがCS-30, 開眼片足立ちテストとは有

表 1. 各測定項目の平均值 $(\mathrm{n}=13)$

\begin{tabular}{llrr}
\hline & & 平均值 & 標準偏差 \\
\hline $50 \mathrm{~m}$ 歩行テスト & (秒) & 29.4 & 5.0 \\
5 m歩行時間 & (秒) & 2.3 & 0.2 \\
大腿四頭筋筋力 & $(\%)$ & 50.4 & 11.3 \\
CS-30 & (回) & 26.4 & 6.0 \\
開眼片足立ちテスト & (秒) & 73.6 & 50.2 \\
TUG & (秒) & 4.8 & 0.7 \\
\hline
\end{tabular}

表 2. 各変数間の相関分析 $(n=13)$

\begin{tabular}{lcc}
\hline & $50 \mathrm{~m}$ 歩行テスト & $5 \mathrm{~m}$ 歩行時間 \\
\hline 大腿四頭筋筋力 & $-0.62^{*}$ & $-0.57^{*}$ \\
CS-30 & $-0.90^{* *}$ & -0.33 \\
開眼片足立ちテスト & $-0.70^{* *}$ & -0.45 \\
TUG & $0.89^{* *}$ & $0.62^{*}$ \\
\hline
\end{tabular}

ピアソンの相関係数, ${ }^{*}: \mathrm{p}<0.05,{ }^{* *}: \mathrm{p}<0.01$ 
意な相関は認められなかった（表 2 ）。

\section{IV 考 察}

本研究は, 高齢者のための新たな歩行能力の評価指 標として開発した $50 \mathrm{~m}$ 歩行テストの基準関連妥当性に ついて検討した。 $50 \mathrm{~m}$ 歩行テストの $20 \mathrm{~m}, 30 \mathrm{~m}, 40 \mathrm{~m}$ の各々 $10 \mathrm{~m}$ の歩行時間に有意差は認められなかった。 高齢者の歩行速度の低下の原因は下肢筋力の低下とさ れている2)。日本人高齢者に打ける $5 \mathrm{~m}$ 歩行時間の参 照值は2.86（95\%CI：2.69〜3.02）秒と報告されて いる ${ }^{16)}$ 。本研究の対象者は参照值よりも速いことから, 高い歩行能力を有していると判断できる。このことか ら, 高齢者は最速歩行で $50 \mathrm{~m}$ を歩いても疲労による ラップ間の変動はなかったのであろう。

次に, $50 \mathrm{~m}$ 歩行テストと身体機能との関連について 検討した。その結果， $50 \mathrm{~m}$ 歩行テストは大腿四頭筋筋 力, CS-30, 開眼片足立ちテスト, TUG との間に有 意な相関が認められた。一方, $5 \mathrm{~m}$ 歩行時間は大腿四 頭筋筋力およびTUG と有意な相関が認められたが, CS-30および開眼片足立ちテストとは有意な相関は認 められなかった。このことから，50m歩行テストは， 高齢男性の下肢筋力, 歩行バランス能力のみならず, 持久力, 動的バランス能力を捉えることができる評価 法であることが確認された。また， $5 \mathrm{~m}$ 歩行時間では 持久力およびバランス能力を捉えることが困難である ことが明らかになった。正常歩行が可能な者には $5 \mathrm{~m}$ 歩行速度では身体機能を十分に捉える事ができないこ とが報告されている ${ }^{11)}$ 。本研究の結果から地域在住高 齢者の身体機能を捉えるには, 短距離の歩行課題では なく一定以上の歩行距離の課題が必要であると考えら れる。地域在住高齢者を対象とした場合, $5 \mathrm{~m}$ 歩行時 間よりも50m歩行テストの方が身体機能をより反映す る評価法である可能性が示唆された。

これらの知見から， $50 \mathrm{~m}$ 歩行テストは $5 \mathrm{~m}$ 歩行時間 と比べて高齢者の身体機能を反映するための簡便な歩 行能力評価であることが確認された。ただし, 本研究 では対象者を男性高齢者に限定したため, 今回の結果 が女性高齢者にも該当するとは限らない。今後は, 女 性へも適応可能か否かついて調查をすすめ, $50 \mathrm{~m}$ 歩行 テストと身体機能との関係を性別に検討する必要があ る。

\section{参考文献}

1）臼田滋, 山端るり子, 遠藤文雄 : 地域在住女性高齢者のバ
ランス能力と下肢筋力, 歩行能力との関連性. 理学療法科 学, 1999, 14(1): 33-36.

2 ) 田井中幸司, 青木純一郎：高齢女性の歩行速度の低下と体 力. 体力科学, $2002,51(2): 245-251$.

3 ) 村田伸, 大田尾浩, 村田潤 - 他 : 虚弱高齢者に扮ける Timed Up and Go Test, 歩行速度, 下肢機能との関連. 理学療法 科学, 2010, 25(4) : 513-516.

4 ) 角田憲治, 辻大士, 尹智暎 - 他 : 地域在住高齢者の余暇活 動量, 家庭内活動量, 仕事関連活動量と身体機能との関連 性. 日本老年医学会雑誌, 2010, 47(6)：592-600.

5 ) 木藤伸宏, 井原秀俊, 三輪恵・他：高齢者の転倒予防とし ての足指トレーニング効果. 理学療法学, 2001, 28(7)： 313-319.

6 ）山田実, 上原稔章：二重課題条件下での歩行時間は転倒の 予測因子となりうる一地域在住高齢者を対象とした前向き 研究一。理学療法科学, 2007, 22(4) : 505-509.

7 ) 文部科学省：新体力テストー有意義な活用のために一. ぎょ うせい, 東京, 2000, p126。

8 ）西嶋尚彦, 大塚慶輔, 鈴木宏哉：地域在住中高齢者の運動 教室参加に打ける筋力と歩行能力発達との因果関係. 体力 科学, 2003, $52:$ 203-212.

9 ) ATS Committee on Proficiency Standards for Clinical Pulmonary Function Laboratories: ATS statement: guidelines for the six-minute walk test. Am J Respir Crit Care Med. 2002, 166(1): 111-117.

10) Bohannon RW : Comfortable and maximum walking speed of adults aged 20-79 years: reference values and determinants. Age Ageing, 1997, 26(1): 15-19.

11) Buchner DM, Larson EB, Wagner EH, et al. : Evidence for a non-linear relationship between leg strength and gait speed. Age Ageing, 1996, 25(5): 386-391.

12) Podsiadlo D, Richaedson S: The Timed "Up \& Go": A test of basic functional mobility for frail elderly persons. J Am Geriatr Soc, 1991, 39(2): 142-148.

13）杉浦美穂, 長崎浩, 古名丈人 - 他 : 地域高齢者の歩行能力 - 4 年間の縦断変化一。体力科学, 1998, 47(4) : 443-452.

14）村田伸, 大山美智江, 大田尾浩：地域在住高齢者の足把持 力に関する研究一性差および年代別の比較一. 理学療法科 学, 2007, 22(4): 499-503.

15）中谷敏昭, 灘本雅一, 三村寛一・他：日本人高齢者の下肢 筋力を簡便に評価する 30 秒椅子立ち上がりテストの妥当性. 体育学研究, 2002, 47(5)：451-461.

16）安藤雅峻, 上出直人：地域在住日本人高齢者における $5 \mathrm{~m}$ 歩行時間の参照值ーメ夕分析による算出. 総合リハビリ テーション, 2013, 41(10)：961-967. 